J. Lake Sci.(湖泊科学), 2016, 28(4): 802-811

DOI 10. 18307/2016. 0413

(c) 2016 by Journal of Lake Sciences

\title{
三峡水库消落区典型草本植物氮、磷养分计量特征”
}

\author{
米玮洁, 邹怡, 李明, 陈明秀, 董方勇** \\ ( 水利部中国科学院水工程生态研究所水利部水工程生态效应与生态修复重点实验室,武汉 430079)
}

\begin{abstract}
摘 要: 为明确消落区土壤养分对植物生长的影响,通过室内栽培试验, 研究三峡库区䄰归消落区土壤 3 种氮磷水平下 4 种草本植物一鬼针草 (Bidens pilosa)、苍耳(Xanthium sibiricum)、水苶 (Polygonum hydropiper)、藜 (Chenopodium album) 长势 及氮、磷计量特征. 结果表明, 消落区土壤中生长的植物氮含量为 $7.98 \sim 19.4 \mathrm{mg} / \mathrm{g}$, 磷含量为 $0.740 \sim 3.880 \mathrm{mg} / \mathrm{g}$, 氮磷比为 $3.48 \sim 13.70$, 判别植物生长受氮限制. 外源氮磷的添加促进植物氮、磷含量明显升高, 但氮磷比没有明显变化; 外源氮磷添 加解除植物受氮的限制作用. 4 种植物对消落区土壤低氮环境具有一定的适应能力. 比较消落区土壤中 4 种植物长势, 鬼 针草生物量、相对生长率、根茎生物量比最高,氮磷养分丰富对鬼针草生长促进作用最明显, 表明鬼针草更易于在氮、磷 贫乏的三峡库区消落区形成优势群落.
\end{abstract}

关键词: 消落区; 氮; 磷; 氮磷比;氮限制; 根茎比; 三峡水库

\section{Nitrogen and phosphorus stoichiometry characteristics of typical herb plants in the water- fluctuation-zone of Three Gorges Reservoir}

\section{Weijie, ZOU Yi, LI Ming, CHEN Mingxiu \& DONG Fangyong***}

( Key Laboratory of Ecological Impacts of Hydraulic-Projects and Restoration of Aquatic Ecosystem of Ministry of Water Resources, Institute of Hydroecology, Ministry of Water Resources and Chinese Academy of Sciences, Wuhan 430079, P.R.China)

Abstract: Nitrogen $(\mathrm{N})$ and phosphorus $(\mathrm{P})$ availability limit plant growth in most terrestrial ecosystems. Plastic responses of plants to $\mathrm{N}$ and $\mathrm{P}$ supply cause variation in biomass and $\mathrm{N} / \mathrm{P}$ ratios, associated with differences in root allocation, nutrient uptake, biomass turnover and reproductive output. We investigated the growth characteristics and nutrients acquirement of four dominant herb plant species (Bidens pilosa, Xanthium sibiricum, Polygonum hydropiper, and Chenopodium album) sampled from Zigui water-fluctuation-zone of Three Gorges Reservoir by pots cultivation at three $\mathrm{N}$ and P levels. In the process of plant growth, we determined plant biomass and nutrient contents of plant tissues. $\mathrm{N}$ contents of plant growing in soil ranged in $7.98-19.4 \mathrm{mg} / \mathrm{g}$, and P, ranged in $0.740-3.880 \mathrm{mg} / \mathrm{g}$, and $\mathrm{N} / \mathrm{P}$, ranged in 3.48-13.70, which indicated that plants were under $\mathrm{N}$ limitation. After $\mathrm{N} \& \mathrm{P}$ supply, $\mathrm{N}$ and $\mathrm{P}$ contents increased significantly, and plant growth were not limited by $\mathrm{N}$. By comparing the growth characteristics of 4 plant species in soil, the following results were obtained. B. pilosa had significant higher biomass, relative growth rate and root/shoot biomass ratio. After $\mathrm{N} \& \mathrm{P}$ supply, B. pilosa growth were promoted significantly. B. pilosa would be dominant community in soil of poor nutrient level in water-fluctuation-zone of Three Gorges Reservoir.

Keywords: Water-fluctuation-zone; nitrogen; phosphorus; N/P ratio; nitrogen limitation; root/shoot biomass ratio; Three Gorges Reservoir

水库消落区是指水库调度引起水位变动,使水陆衔接地带的土地被周期性淹没和出露而形成的干湿交 替地带, 它表现出一定的生态脆弱性. 水库消落区往往存在植被破坏、生物多样性下降、小气候恶化、河床及 河岸遭受侵蚀等生态环境问题 ${ }^{[1-3]}$. 从 2003 年三峡库区完成 $135 \mathrm{~m}$ 蓄水目标, 到 2010 年三峡大坝坝前水位

* 国家水体污染控制与治理科技重大专项(2009ZX07104-003-04)资助.2015-06-18 收稿;2015-10-26 收修改稿. 米玮洁 (1980 ), 女, 博士, 助理研究员; E-mail: miweijie@ mail.ihe.ac.cn.

** 通信作者;E-mail: dfy1008@ mail.ihe.ac.cn. 
达 $175 \mathrm{~m}$, 落差达 $30 \mathrm{~m}$ 的水库消落区全部形成. 三峡消落区维管束植物以草本植物为主, 且以一年生草本植 物居多 ${ }^{[4]}$. 从 2001 年开始, 国内开展一系列三峡消落区植被群落调查工作, 研究三峡库区消落区植被的恢 复、生长与结构特征、演替过程 ${ }^{[5-13]}$. 消落区淹水时间、土壤湿度和土壤质地是影响植物群落组成和空间分布 的主要因子 ${ }^{[14]}$. 三峡消落区不同高程受淹时间由短到长, 环境湿度梯度由干燥到湿润, 消落区土壤呈现明 显的分层结构, 植被也呈现明显的分层结构 ${ }^{[5-7,15]}$. 植物生长过程中, 土壤氮磷养分水平及限制作用对植物 生长及种间竞争具有重要影响 ${ }^{[16-17]}$, 进而改变植物群落组成及多样性 ${ }^{[18]}$, 引起植物群落发生演替 ${ }^{[19]}$. 因此, 消落区土壤养分供应影响消落区植物的生长、种群结构及稳定性.

植物营养元素化学特征与环境的关系, 反映了植物对环境的适应能力. 植物氮磷生态化学计量特征是 植物群落结构和功能的一种内在调控机制 ${ }^{[20]}$, 是揭示植物养分限制状况及其适应策略的重要手段. 近年来 生态化学计量学理论在植物方面的研究与应用主要侧重于: 1) 植物生长、群落特征与生态化学计量特征的 关系; 包括植物不同器官 ${ }^{[21]}$ 、不同生长期 ${ }^{[22-23]}$ 的生态化学计量特征变化; 植物物种多样性 ${ }^{[24]}$ 、群落演替 ${ }^{[25-26]}$ 与生态化学计量的关系. 2) 环境与植物生态化学计量特征的相互作用:包括土壤 ${ }^{[27-28]}$ 、施肥 ${ }^{[29-30]}$ 、放牧 ${ }^{[31]}$ 等 环境因素对植物生态化学计量特征的影响. 也开始关注湿地、河岸带/湖滨带植物的生态化学计量特征 ${ }^{[32]}$, 主要研究了山地沼泽湿地 ${ }^{[33]}$ 、湖滨带 ${ }^{[34]}$ 、河口 ${ }^{[35]}$ 、潮滩地 ${ }^{[36]}$ 、滩涂湿地 ${ }^{[37]}$ 土壤与植物的生态化学计量学特 征, 但有关消落区植物的养分计量特征、消落区自然恢复的草本植物群落与消落区土壤养分水平相互作用 的研究还很少. 植物营养计量学为消落区草本植物生长及竞争关系研究提供了一个新的途径, 为揭示三峡 库区消落区植物群落变化趋势并为库区生态保护与重建提供科学依据.

为了明确消落区植物对氮磷养分的吸收利用特点, 本文以三峡库区消落区天然草本植物群落中的常见 种 (鬼针草 (Bidens pilosa)、苍耳 (Xanthium sibiricum)、水苶 (Polygonum hydropiper)、藜 (Chenopodium album)) 为研究对象, 在人工控制氮磷营养水平的条件下, 分析植物在不同养分条件下的氮磷化学计量特征, 比较 4 种植物的氮磷吸收特征与生长特征, 以期揭示植物的养分利用状况, 判断植物生长限制因子和限制程度等, 以便探讨其在消落区具有区域性特点生长的养分特征. 旨在研究三峡库区消落区土壤氮磷养分对草本植物 生长的影响, 为消落区草本植物生长与群落演替提供理论基础.

\section{1 材料与方法}

\section{1 材料}

供试土壤: 取自三峡库区缓坡消落区䄰归县九曲垴渡口 $\left(30^{\circ} 53^{\prime} \mathrm{N}, 110^{\circ} 53^{\prime} \mathrm{E}\right.$; 海拔 $\left.160 \mathrm{~m}\right)$. 样地邻近区 域年均气温 $18^{\circ} \mathrm{C}$, 年均降雨量 $1100 \mathrm{~mm}$, 坡度 $36^{\circ}$, 母岩为花岗岩, 土壤类型为黄壤土, 土层厚度 $40 \mathrm{~cm}$ 左右, 植被为人工马尾松 (Pinus massoniana) 林. 土壤取回晾干后过 $3 \mathrm{~mm}$ 篮, 混匀, 测定土壤的 $\mathrm{pH}$ 值、有机质含量 及氮磷含量 $($ 表 1$)$.

表 1 三峡库区䄰归消落区供试土壤基本理化特征

Tab.1 Basic chemical characteristics of soil in Zigui water-fluctuation-zone of Three Gorge Reservoir

\begin{tabular}{ccccccc}
\hline & $\mathrm{pH}$ 值 & 有机质 $/(\mathrm{g} / \mathrm{kg})$ & 碱解氮 $/(\mathrm{mg} / \mathrm{kg})$ & 总氮 $/(\mathrm{g} / \mathrm{kg})$ & 有效磷 $/(\mathrm{mg} / \mathrm{kg})$ & 总磷 $/(\mathrm{g} / \mathrm{kg})$ \\
\hline 消落区土壤 & 6.28 & 4.82 & 24.7 & 0.281 & 0.396 & 0.117 \\
\hline
\end{tabular}

供试植物 : 根据 2009 年 5-9 月在三峡水库消落区出露期间对库区典型干流消落区和库湾消落区植被 进行的调查, 选择优势植物鬼针草、苍耳、水蓼、藜作为研究对象. 植物幼苗取自三峡库区缓坡消落区兴山县 香溪河流域消落区 (昭君镇昭君村, $31^{\circ} 15^{\prime} \mathrm{N}, 110^{\circ} 44^{\prime} \mathrm{E}$; 海拔 $166 \mathrm{~m}$; 峡口镇黄家沟, $31^{\circ} 10^{\prime} \mathrm{N}, 110^{\circ} 46^{\prime} \mathrm{E}$; 海 拔 $162 \mathrm{~m}$ ). 取回实验室后, 洗去根系上的土壤, 选取长势、生物量稍一致的幼苗, 种在装有消落区土壤的盆 钵中.

\section{2 实验设置}

2010 年 6-9 月在三峡大学化学与生命科学学院温室大棚进行消落区植物栽培实验. 根据草本植物盆 栽实验研究 ${ }^{[38]}$, 本文设置 3 个施肥梯度: $\mathrm{N}_{0} \mathrm{P}_{0}\left(0 \mathrm{~g} \mathrm{~N} / \mathrm{kg}\right.$ 土、 $0 \mathrm{~g} \mathrm{P}_{2} \mathrm{O}_{5} / \mathrm{kg}$ 土 $) 、 \mathrm{~N}_{1} \mathrm{P}_{1}(0.2 \mathrm{~g} \mathrm{~N} / \mathrm{kg}$ 土、0.2 g $\mathrm{P}_{2} \mathrm{O}_{5} / \mathrm{kg}$ 土 $) 、 \mathrm{~N}_{2} \mathrm{P}_{2}\left(0.5 \mathrm{~g} \mathrm{~N} / \mathrm{kg}\right.$ 土、 $0.4 \mathrm{~g} \mathrm{P}_{2} \mathrm{O}_{5} / \mathrm{kg}$ 土 $)$. 氮肥选用 $\left(\mathrm{NH}_{4}\right)_{2} \mathrm{SO}_{4}$ 、磷肥选用 $\mathrm{Ca}\left(\mathrm{H}_{2} \mathrm{PO}_{4}\right)_{2} \cdot \mathrm{H}_{2} \mathrm{O}$. 
将固体肥料与土壤拌匀后, 装人 $2 \mathrm{~L}$ (盆口直径 $15 \mathrm{~cm}$ ) 的塑料桶, 每个处理 9 个重复. 2010 年 6 月 11 日种植 植物幼苗, 每桶种一株株高稍一致、重量 $2.5 \sim 3.0 \mathrm{~g}$ 的植物幼苗, 每种植物种 27 盆. 植物生长过程中用量筒 添加蒸馏水补充水分. 分别于 7 月 6 日、7月 29 日、8 月 15 日取样, 每次取样每个处理 3 个重复, 分别测定植 物生物量及氮磷含量.

\section{3 测定指标与方法}

风干土壤样品、烘干植物样品粉碎后过 $0.149 \mathrm{~mm}$ 篮, 用于测定分析 ${ }^{[39]}$ : 土壤有机质含量采用重铬酸钾 容量法测定; 土壤 $\mathrm{pH}$ 值采用玻璃电极法测定; 土壤全氮含量采用 $\mathrm{K}_{2} \mathrm{SO}_{4}-\mathrm{CuSO}_{4}-\mathrm{Se}$ 蒸馏-半微量凯氏法测 定; 土壤有效氮含量采用碱解扩散法测定; 土壤有效磷含量采用 $0.5 \mathrm{~mol} / \mathrm{L} \mathrm{NaHCO}_{3}$ 浸提一钿锑抗比色法测定. 植物样品用 $\mathrm{H}_{2} \mathrm{SO}_{4}-\mathrm{H}_{2} \mathrm{O}_{2}$ 消解后, 植物氮含量采用凯氏定氮法测定, 植物磷含量采用钿锑抗比色法测定.
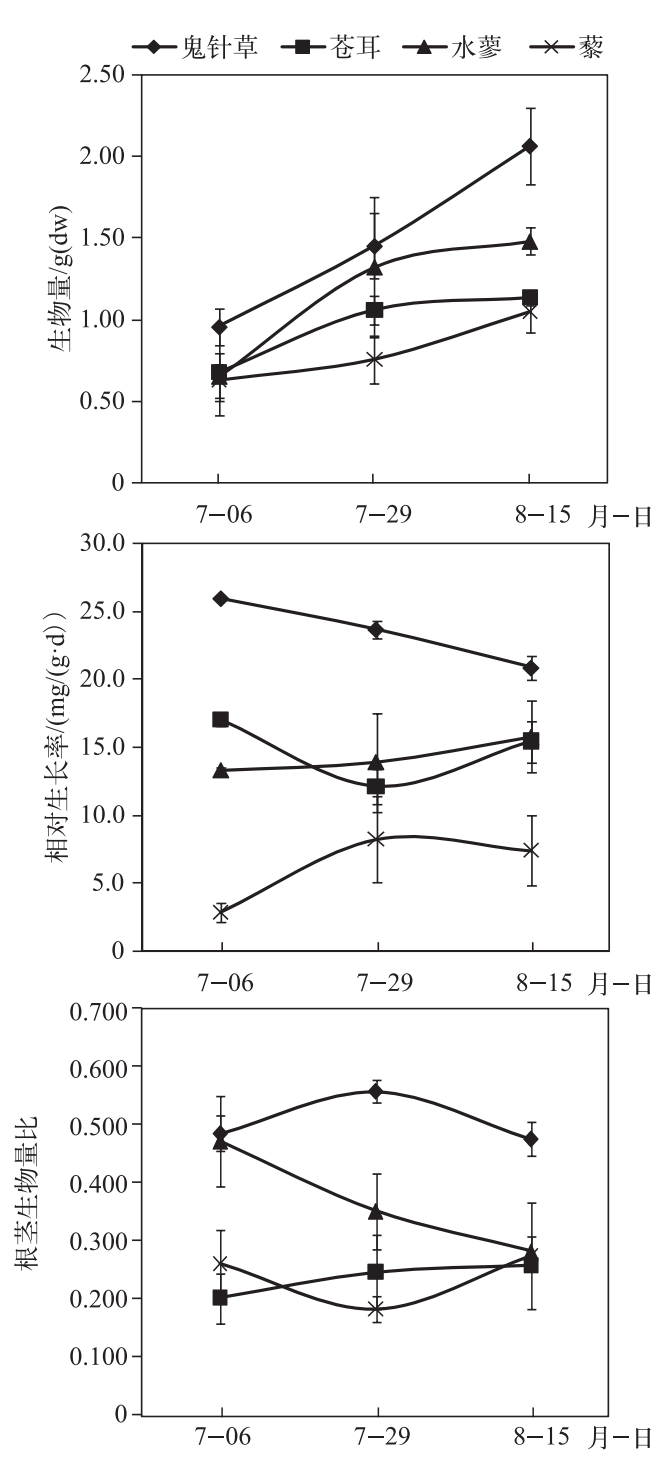

图 1 三峡水库消落区土壤中植物的生长特征

Fig.1 Plant growth in soil of water-levelfluctuation zone of Three Gorges Reservoir

\section{4 数据处理}

使用 SPSS 13.0 软件进行数据处理、统计分析: 采 用单因素方差分析 (One-way ANOVA) 比较消落区不同 植物种类长势、氮磷计量特征的差异; 采用单变量多因 素方差分析 (GLM Univariate) 植物种类、采样时间、氮 磷水平对植物长势、氮磷计量特征的影响. 方差分析过 程中, 首先进行方差齐性检验; 方差齐性, 选择 $\mathrm{S}-\mathrm{N}-\mathrm{K}$ 进行多重比较; 方差非齐性, 选择 Tamhane's T2 进行多 重比较.

\section{2 结果与分析}

\section{1 消落区植物的生长特征及对土壤氮磷水平的响应}

消落区土壤 $\left(\mathrm{N}_{0} \mathrm{P}_{0}\right.$ 水平 $)$ 中鬼针草、苍耳、水蓼、葱 均长势良好. 4 种植物的生物量差异明显 $(P<0.01)$ : 鬼 针草生物量最高, 其次为水苶、苍耳, 藜生物量最低; 不 同采样时间植物生物量也表现出明显差异 $(P<0.01)$ : 随着生长, 植物生物量明显增加; 其中鬼针草生物量增 加最明显, 其次是水苶 (图 1). 4 种植物相对生长率差 异显著 $(P<0.01)$ : 鬼针草相对生长率最高, 其次为水 苶、苍耳, 僽相对生长率最低; 不同采样时间植物相对 生长率差异不明显 $(P=0.935)$ ( 图 1). 4 种植物根茎生 物量比差异明显 $(P<0.01)$ : 鬼针草根茎生物量比最高, 其次为水蓼, 苍耳、愁根茎生物量比较低; 不同采样时 间植物根茎生物量比差异不明显 $(P=0.520)$ ( 图 1).

比较不同土壤氮磷水平 $\left(\mathrm{N}_{0} \mathrm{P}_{0} 、 \mathrm{~N}_{1} \mathrm{P}_{1}\right.$ 和 $\left.\mathrm{N}_{2} \mathrm{P}_{2}\right)$ 中消 落区植物的长势差异 (图 2): 与 $\mathrm{N}_{0} \mathrm{P}_{0}$ 处理相比, $\mathrm{N}_{1} \mathrm{P}_{1}$ 处 理中除苍耳生物量 $(P=0.404)$ 、根茎生物量比 $(P=$ $0.122)$ 没有明显变化外, 其余植物生物量、相对生长率 显著增加 $(P<0.01)$, 根茎生物量比显著降低 $(P<0.01)$. 与 $\mathrm{N}_{1} \mathrm{P}_{1}$ 处理相比, $\mathrm{N}_{2} \mathrm{P}_{2}$ 处理中除鬼针草相对生长率显 著增加 $(P<0.01)$ 外, 其余植物生物量 $(P=0.501)$ 、相对 生长率 $(P=0.367)$ 、根茎生物量比 $(P=0.480)$ 均没有显 著差异. 4 种植物相比, 植物生物量、相对生长率差异显 著 $(P<0.01)$, 其中, 鬼针草生物量、相对生长率最高, 其 次为苍耳、水苶, 僽生物量、相对生长率最低; 4 种植物 
根茎生物量比没有显著差异 $(P=0.179)$.

\section{2 消落区植物氮磷计量特征及对土壤氮磷水平的响应}

比较消落区土壤 ( $\mathrm{N}_{0} \mathrm{P}_{0}$ 水平) 中 4 种植物的氮磷含量及 氮磷比 (图 3 ) : 消落区土壤中, 植物氮含量范围为 $7.98 \sim$ $19.35 \mathrm{mg} / \mathrm{g}, 4$ 种植物氮含量没有明显差异 $(P=0.185)$. 随 着生长, 植物氮含量明显下降 $(P<0.01)$, 其中, 僽氮含量变 化最大, 鬼针草氮含量变化最小. 植物磷含量范围为 $0.74 \sim$ $3.88 \mathrm{mg} / \mathrm{g}, 4$ 种植物磷含量差异显著 $(P<0.01)$, 苍耳磷含量 最高, 其次为鬼针草、栳, 水苶磷含量最低. 随着生长, 植物 磷含量显著下降 $(P<0.01)$, 其中, 苍耳磷含量变化最大, 鬼 针草磷含量变化最小. 植物氮磷比范围为 $3.48 \sim 13.73,4$ 种 植物氮磷比差异显著 $(P<0.01)$ : 水苶氮磷比最高, 其次为 䓇, 苍耳、鬼针草氮磷比较低. 随着植物生长, 植物氮磷比明 显增加 $(P<0.01)$, 其中鬼针草氮磷比增加最明显 (图 3).

比较不同土壤氮磷水平 $\left(\mathrm{N}_{0} \mathrm{P}_{0} 、 \mathrm{~N}_{1} \mathrm{P}_{1}\right.$ 和 $\left.\mathrm{N}_{2} \mathrm{P}_{2}\right)$ 中消落区 植物的氮磷含量、氮磷比 (图 4): 与 $\mathrm{N}_{0} \mathrm{P}_{0}$ 处理相比, $\mathrm{N}_{1} \mathrm{P}_{1}$ 处 理中消落区植物氮、磷含量显著增加 $(P<0.01)$; 氮磷比除水 苶显著降低 $(P<0.01)$ 外, 其余植物均没有表现出显著差异 $\left(P_{\text {Bid }}=0.359, P_{\text {Xan }}=0.106, P_{\text {Che }}=0.056\right)$. 与 $\mathrm{N}_{1} \mathrm{P}_{1}$ 处理相比, $\mathrm{N}_{2} \mathrm{P}_{2}$ 处理中鬼针草氮含量显著增加 $(P<0.01)$, 水苶氮含量显 著降低 $(P<0.01)$, 苍耳、藜氮含量均没有显著差异 $\left(P_{\mathrm{Xan}}=\right.$ $\left.0.665, P_{\mathrm{Che}}=0.404\right)$. 除鬼针草磷含量没有显著变化 $(P=$ $0.436)$ 外, 其余植物磷含量均显著降低 $(P<0.01)$. 除苍耳氮 磷比显著增加 $(P<0.01)$ 外, 其余植物氮磷比均没有明显变 化 $\left(P_{\mathrm{Bid}}=0.093, P_{\mathrm{Pol}}=0.938, P_{\mathrm{Che}}=0.195\right) .4$ 种植物相比, 植 物氮含量、磷含量、氮磷比均差异显著 $(P<0.01)$, 其中, 苍耳 氮含量最低, 水苶磷含量最低, 水苶氮磷比最高.

\section{3 讨论}

\section{1 消落区植物生长的限制性因子}

三峡库区消落区土壤受水位涨落的影响, 土壤物理性 状发生改变, 土壤养分含量总体呈下降趋势 ${ }^{[40]}$. 郭劲松等 调查三峡库区巫山-重庆主城区段消落区土壤, 认为三峡消 落区有机质、TN 含量处于偏低水平 ${ }^{[41]}$. 将本次取样的消落 区土壤氮磷含量与 2008 年整个消落区土壤氮磷含量 ${ }^{[42]}$ 相 比, 本次取样消落区土壤的氮磷含量处于较低水平. 与蓄水 前三峡水库剓归段库岸土壤养分特征 ${ }^{[43]}$ 相比, 蓄水后剓归 消落区土壤氮磷含量明显下降. 这可能与消落区淹水-出露 过程有关, 消落区土壤经淹水-出露过程后, 土壤中氮磷水
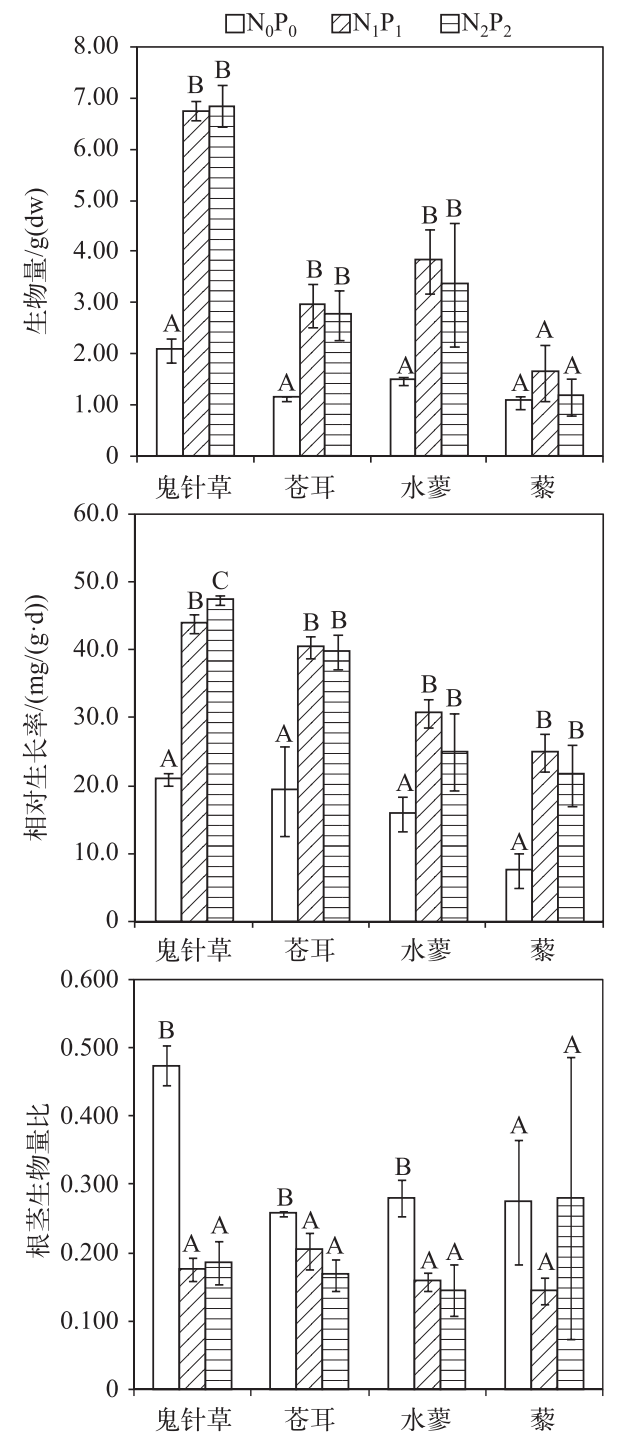

图 2 三峡水库不同氮磷水平消落区 土壤中植物的生长特征

$(A 、 B 、 C$ 表示同一植物不同氮、磷 水平差异显著 $(P<0.05)$,下图同 $)$

Fig.2 Plant growth in soil with different $\mathrm{N} \&$

$\mathrm{P}$ levels of water-level-fluctuation zone of Three Gorges Reservoir 平明显降低 ${ }^{[4]]}$. 此外, 植物生长也会对消落区土壤养分产生影响. Ye 等研究发现三峡库区消落区植被短期 恢复-淹水过程中,土壤无机氮含量明显下降, 土壤有机碳以及碳氮比也发生明显变化 ${ }^{[45]}$.

三峡库区䄰归消落区土壤中生长的鬼针草、苍耳、水苶、藜氮含量为 $7.98 \sim 19.35 \mathrm{mg} / \mathrm{g}(<20 \mathrm{mg} / \mathrm{g})$, 磷含 量为 $0.74 \sim 3.88 \mathrm{mg} / \mathrm{g}$, 氮磷比为 $3.48 \sim 13.73(<14)$. 利用氮磷比作为植物氮磷限制因子的指示, 根据 Aerts \& Chapin ${ }^{[46]}$ 和 Ellison ${ }^{[47]}$ 给出的临界值作为氮磷限制作用的判断标准, 三峡库区䄰归消落区土壤中 4 种植物的 

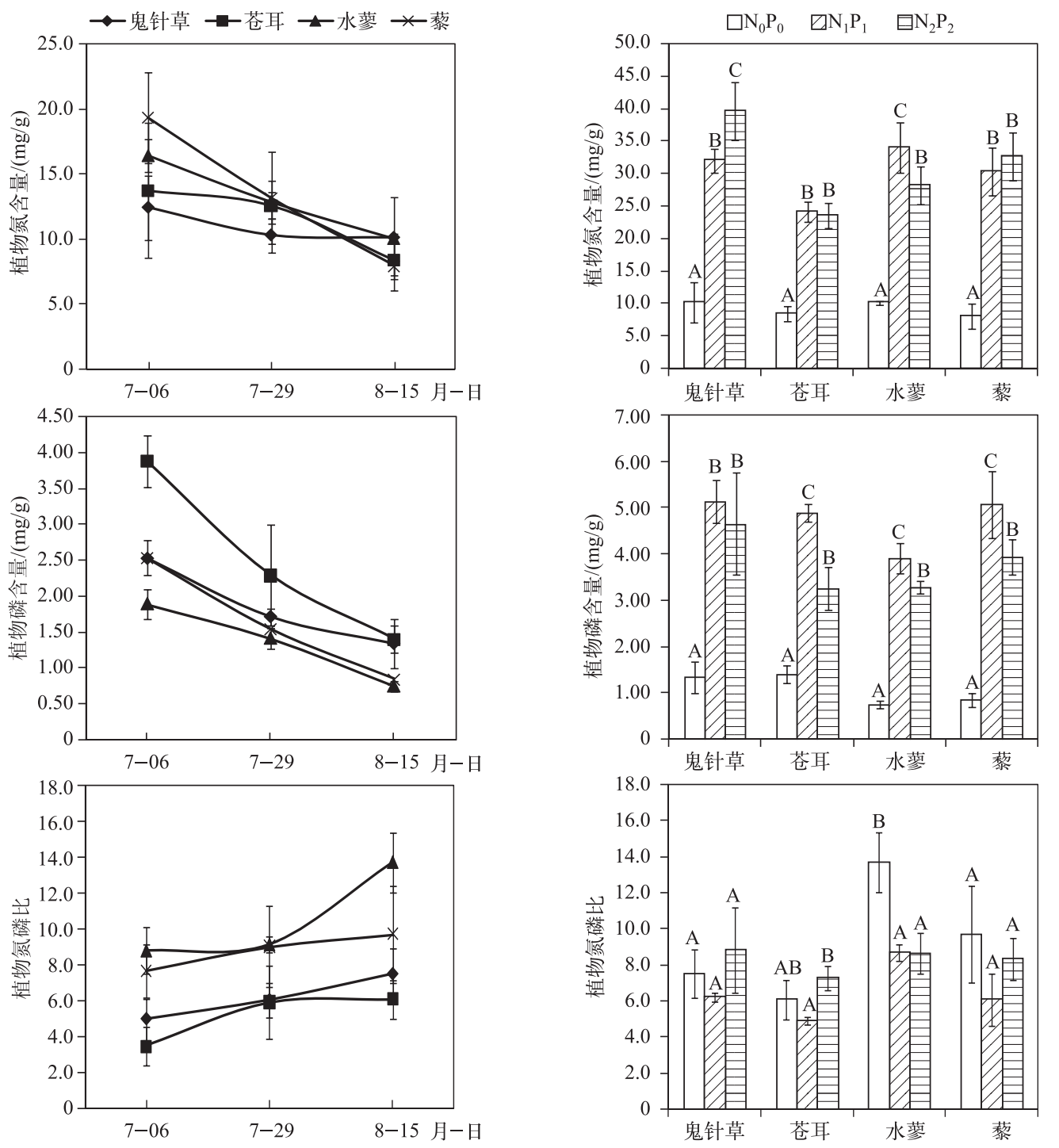

图 3 三峡水库消落区土壤中植物的 氮磷计量特征

Fig.3 N \& P stoichiometry characteristics of plant growing in soil of water-level-fluctuation zone of Three Gorges Reservoir

图 4 三峡水库不同氮磷水平消落区 土壤中植物的氮磷计量特征

Fig.4 N \& P stoichiometry characteristics of plant growing in soil with different N \& P levels of water-level-fluctuation zone of Three Gorges Reservoir

生长处于氮限制状态. 与其他消落区/河岸带草本植物氮磷含量特征 ${ }^{[48]}$ 相比, 本研究中植物的氮磷含量及 氮磷比范围较相近, 而且都处于氮限制状态, 这可能与淹水-退水过程中, 土壤中氮含量下降比磷含量更为 明显有关 ${ }^{[4]}$. 消落区土壤氮磷添加后, 植物氮磷含量也明显增加, 氮含量 $>20 \mathrm{mg} / \mathrm{g}$, 磷含量 $>1 \mathrm{mg} / \mathrm{g}$. 根据 Aerts \& Chapin ${ }^{[46]}$ 和 Ellison ${ }^{[47]}$ 给出的临界值判断, 此时植物不再受氮限制.

\section{2 消落区植物生长的养分利用策略}

根据 Tilman 的竞争资源比理论: 在较长的时间里, 营养元素含量降低的物种较适于在元素匮乏的地区 生长, 氮磷含量降低的植物在 N-限制或 P-限制的环境下会成为优势物种 ${ }^{[49]}$. 一般来说, 低氮含量、低 $\mathrm{N}: \mathrm{P}$ 
比的植物适应氮限制类型的土壤. 李小峰等通过研究百花湖消落带植物养分元素特征, 也认为禾本科、苶 科、菊科植物中的营养元素含量较低, 又具有一定的耐水淹性, 适宜在消落区水淹时间较长且土壤中氮磷营 养元素含量较低的特殊环境下生长 ${ }^{[50]}$. 本研究中, 消落区土壤中鬼针草、苍耳、水蓼、藜氮磷含量均较低, 而 且随着植物生长氮磷含量表现出明显的下降趋势, 氮磷比呈增加趋势, 这是消落区 4 种优势草本植物对消 落区土壤低氮环境的适应,通过降低磷吸收,增加氮磷比,缓解氮限制作用.

在三峡库区剓归消落区土壤中, 虽然判断鬼针草、苍耳、水苶、栳均处于氮限制, 但这 4 种植物长势良 好, 其中鬼针草长势最好, 表现为鬼针草生物量最高、相对生长率最高, 根茎生物量比也最高. 在生长过程 中, 鬼针草向根系分配的生物量比例明显高于其他 3 种植物, 这可能是鬼针草在氮限制的消落区土壤中长 势最好的原因之一. 植物生长过程中根茎生物量比变化是对环境养分的一种适应策略. 例如, 环境低氮水平 时, 植物会增加吸收器官的生物量分配, 有利于养分吸收; 环境高氮水平时, 植物将更多的生物量投人同化 器官, 有利于碳积累 ${ }^{[1]}$. 氮限制时, 植物根系分配的生物量越多, 表明其对氮的竞争作用越强 ${ }^{[18]}$. 因此,三峡 库区消落区植物在氮限制条件下, 鬼针草根系生长的能力更强, 向根系分配更多生物量, 进而促进鬼针草对 氮的吸收.

外源养分丰富会促进植物生长, 增加植物株高、叶片或茎条数、生物量, 降低植物根系生物量比 ${ }^{[51-52]}$. 本 研究中土壤氮磷添加促使植物生物量、相对生长率明显增加, 根茎生物量比明显降低. 因此, 土壤氮磷丰富 对消落区植物生长的影响表现在:1) 促进植物生长、生物量的累积,2) 减少植物生物量向根系分配. 当氮素 不再是植物生长的限制因子时, 植物会分配更多的生物量到碳同化器官, 促进地上部分生长, 使总生物量升 高, 有助于提高植株的竞争能力 ${ }^{[18]}$, 养分增加对植物生长的促进效应越强则植物在竞争中往往处于优势. 本研究中, 土壤氮磷养分增加后, 鬼针草生物量、相对生长率均最高, 表明相较于其他植物而言, 鬼针草对养 分利用更具有优势,养分丰富对鬼针草生长的促进作用更明显.

消落区土壤氮磷丰富明显促进消落区植物氮磷含量增加, 但植物氮磷比没有明显变化, 这是植物养分 计量内稳性的一种表现. 消落区土壤中, 植物氮磷比范围为 $4.95 \sim 15.60$; 土壤氮磷含量增加后, 植物氮磷比 范围为 4.47 11.50. 因此, 即使土壤中氮磷添加后, 促进植物体内氮磷含量增加, 但是由于植物自身的内稳 性调节, 使得氮磷比保持在一定范围内.

综上, 三峡库区䄰归消落区土壤氮限制条件下, 这 4 种优势植物对土壤低氮缓解具有一定的适应能力. 相较之下, 鬼针草在消落区土壤中长势最好, 具有更高的根茎生物量比; 而且当土壤氮磷养分添加后, 对鬼 针草生长促进作用最明显. 因此,与苍耳、水苶、莍相比, 鬼针草对消落区土壤氮磷养分利用能力更强,在三 峡库区消落区更容易成为优势种.

\section{4 参考文献}

[ 1 ] Fan Xiaohua, Xie Deti, Wei Chaofu. Study on countermeasures for ecological environmental protection and utilization of riparian zone of Three Gorge Reservoir. Journal of Soil and Water Conservation, 2006, 20(2): 165-169(in Chinese with English abstract). [范小华, 谢德体, 魏朝富. 三峡水库消落区生态环境保护与利用对策研究. 水土保持学报, $2006,20(2)$ : 165-169.]

[ 2 ] Su Weici, Zhao Chunyong, Yang Hua. Evaluation on natural conditions of water-level-fluctuating zone( WLFZ) in ThreeGorge Reservoir. Scientia Geographica Sinica, 2009, 29(2) : 268-272(in Chinese with English abstract). [苏维词, 赵纯 勇, 杨华. 三峡库区消落区自然条件及其开发利用评价——以重庆库区为例. 地理科学, 2009, 29(2): 268-272.]

[ 3 ] Liu Weiwei, Wang Jie, Wang Yong et al. The differences of plant community diversity among the different altitudes in the water-level-fluctuating zone of the Three Gorges Reservoir. Acta Ecologica Sinica, 2012, 32(17) : 5454-5466(in Chinese with English abstract). DOI 10.5846/stxb201102240211. [刘维暐, 王杰, 王勇等. 三峡水库消落区不同海拔高度的 植物群落多样性差异. 生态学报, 2012, 32(17): 5454-5466.]

[ 4 ] Liu Weiwei, Yang Fan, Wang Jie et al. Plant species dynamic distribution in the water-level-fluctuating zone of the Main Stream and Bay of the Three Gorges Reservoir. Plant Science Journal, 2011, 29(3) : 296-306(in Chinese with English abstract). DOI 10.3724/SP.J.1142.2011.30296. [刘维暐, 杨帆, 王杰等. 三峡水库干流和库湾消落区植被物种动态 分布研究. 植物科学学报, 2011, 29(3): 296-306.] 
[ 5 ] Wang Yong, Li Enhua, Wu Jinqing. A preliminary study on the vascular plant flora of the water-level-fluctuating zone in the Three-Gorge Reservoir area. Journal of Wuhan Botanical Research, 2002, 20(4) : 265-274(in Chinese with English abstract). [王勇, 厉恩华, 吴金清. 三峡库区消涨带维管植物区系的初步研究. 武汉植物学研究, 2002, 20(4): 265-274. ]

[ 6 ] Wang Yong, Wu Jinqing, Huang Hongwen et al. Quantitative analysis of plant communities in water-level-fluctuation zone within Three Gorges Reservoir area of Changjiang River. Journal of Wuhan Botanical Research, 2004, 22(4) : 307-314(in Chinese with English abstract). [王勇, 吴金清, 黄宏文等. 三峡库区消涨带植物群落的数量分析. 武汉植物学研 究, 2004, 22(4) : 307-314.]

[ 7 ] Feng Yilong, Xian Xudong, Wang Haiyang. Distribution patterns of plant communities in the riparian zones in Chongqing and forecasting of the characteristics of their succession after inundation. Journal of Southwest China Normal University (Natural Science)，2007，32(5)：112-117 (in Chinese with English abstract). [冯义龙, 先旭东, 王海洋. 重庆市区 消落带植物群落分布特点及淹水后演替特点预测. 西南师范大学学报: 自然科学版, 2007, 32(5): 112-117.]

[ 8 ] Yang Chaodong, Zhang Xia, Xiang Jiayun. Plant communities and distribution patterns in riparian zones of Three Gorge Reservoir area. Journal of Anhui Agricultral Science, 2008, 36(31): 13795-13796, 13866(in Chinese with English abstract). [ 杨朝东, 张霞, 向家云. 三峡库区消落带植物群落及分布特点的调查. 安徽农业科学, 2008, 36(31): 13795-13796, 13866.]

[ 9 ] Wang Qiang, Yuan Xingzhong, Liu Hong et al. Plant communities in newly created wetlands in water-level fluctuation zone of Three-Gorges Reservoir after flooding to 156m height. Chinese Journal of Ecology, 2009, 28 (11) : 2183-2188( in Chinese with English abstract). [王强, 袁兴中, 刘红等. 三峡水库 $156 \mathrm{~m}$ 蓄水后消落带新生湿地植物群落. 生态学杂 志, 2009, 28(11) : 2183-2188.]

[10] Xia Zhiyong. The distributing characters of plant species and plant community diversity in the water-level-fluctuating zone of the Three Gorges Reservoir [Dissertation]. Chongqing: Southwest University, 2011(in Chinese with English abstract). [夏智勇. 重庆三峡水库消落带植物分布特征与群落物种多样性研究 [学位论文]. 重庆: 西南大学, 2011.]

[11] Zhang Zhiyong, Liu Mingqin, Zheng Zhiwei et al. Plant diversity in water-level-fluctuation zone of Xiaojiang watershed in Three Gorges Reservoir. Journal of Hydroecology, 2011, 32(3) : 38-42(in Chinese with English abstract). [张志永, 刘 明芹, 郑志伟等. 三峡水库小江流域消落区的植物多样性研究. 水生态学杂志, 2011, 32(3): 38-42.]

[12] Li Bo, Xiong Sen, Huang Yazhou et al. Changing patterns of plant communities in the drawdown zone of Baijia Creek under the influence of Three Gorges Reservoir impoundment. Journal of Chongqing Normal University (Natural Science), 2012, 29(3) : 70-74(in Chinese with English abstract). DOI 10.11721/cqnuj20120314. [李波, 熊森, 黄亚洲等. 三峡 水库蓄水对白夹溪消落区的植物群落格局的影响. 重庆师范大学学报: 自然科学版, 2012, 29(3): 70-74.]

[13] Lei Bo, Wang Yechun, You Yongfei et al. Diversity and structure of herbaceous plant community in typical water-levelfluctuation zone with different spacing elevations in Three Gorges Reservoir. J Lake Sci, 2014, 26(4) : 600-606(in Chinese with English abstract). DOI 10.18307/2014.0415. [雷波, 王业春, 由永飞等. 三峡水库不同间距高程消落带草 本植物群落物种多样性与结构特征. 湖泊科学, 2014, 26(4) : 600-606.]

[14] Sun Rong. Study on riparian plant of mountain river-Pengxi River of Three Gorges Reservoir area as a case study [Dissertation]. Chongqing: Chongqing University, 2010(in Chinese with English abstract). [孙荣. 山地河流河岸植被生态学 研究一以三峡库区澎溪河为例 [学位论文]. 重庆:重庆大学, 2010.]

[15] Wang Yechun, Lei Bo, Zhang Sheng. Differences in vegetation and soil characteristics at different water-level altitudes in the drawdown areas of Three Gorges Reservoir area. J Lake Sci, 2012, 24(2) : 206-212(in Chinese with English abstract). DOI 10.18307/2012.0206. [王业春, 雷波, 张星. 三峡库区消落带不同水位高程植被和土壤特征差异. 湖 泊科学, 2012, 24(2): 206-212.]

[16] Zhao Congjiao, Deng Zifa, Zhou Changfang et al. Effects of nitrogen availability and competition on leaf characteristics of Spartina alterniflora and Phragmites australis. Chinese Journal of Plant Ecology, 2008, 32(2) : 392-401 (in Chinese with English abstract). DOI 10.3773/j. issn.1005-264x.2008.02.017. [赵聪蛟, 邓自发, 周长芳等. 氮水平和竞争对互花米 草与芦苇叶特征的影响. 植物生态学报, 2008, 32(2) : 392-401.]

[17] Venterink HO, Güsewell S. Competitive interactions between two meadow grasses under nitrogen and phosphorus limitation. Functional Ecology, 2010, 24(4): 877-886.

[18] Tian Yaohua, Feng Yulong, Liu Chao. Effects of nitrogen fertilization and planting density on Ageratina adenophora growth 
and its competitive traits. Chinese Journal of Ecology, 2009, 28(4) : 577-588(in Chinese with English abstract). [田耀 华, 冯玉龙, 刘潮. 氮肥和种植密度对紫茎泽兰生长和竞争的影响. 生态学杂志, 2009, 28(4) : 577-588.]

[19] Portielje R, Roijackers RMM. Primary succession of aquatic macrophytes in experimental ditches in relation to nutrient input. Aquatic Botany, 1995, 50: 127-140.

[20] Yu Q, Chen Q, Elser JJ et al. Linking stoichiometric homoeostasis with ecosystem structure, functioning and stability. Ecology Letters, 2010, 13: 1390-1399.

[21] Zhao Yafang, Xu Fuli, Wang Weiling et al. Seasonal variation in contents of C, N and P and stoichiometry characteristics in fine roots, stems and needles of Larix principis-rupprechtii. Chinese Bulletin of Botany, 2014, 49(5) : 560-568(in Chinese with English abstract). DOI 10.3724/SP.J.1259.2014.00560. [赵亚芳, 徐福利, 王渭玲等. 华北落叶松根茎叶碳 氮磷含量及其化学计量学特征的季节变化. 植物学报, 2014, 49(5): 560-568.]

[22] Xiao Yao, Tao Ye, Zhang Yuanming. Biomass allocation and leaf stoichiometric characteristics in four desert herbaceous plants during different growth periods in the Gurbantünggüt Desert, China. Chinese Journal of Plant Ecology, 2014, 38 (9) : 929-940( in Chinese with English abstract). DOI 10.3724/SP.J.1258.2014.00087. [ 肖遥, 陶冶, 张元明. 古尔班 通古特沙漠 4 种荒漠草本植物不同生长期的生物量分配与叶片化学计量特征. 植物生态学报, 2014, 38(9): 929-940. ]

[23] Yang Mei, Wang Changquan, Yuan Dagang et al. C, N, P stoichiometry traits of different flue-cured tobacco organs at different growth stages. Chinese Journal of Eco-Agriculture, 2015, 23(6) : 686-693(in Chinese with English abstract). DOI 10.13930/j.cnki.cjea.141289. [杨梅, 王昌全, 袁大刚等. 不同生长期烤烟各器官 C、N、P 生态化学计量学特征. 中 国生态农业学报, 2015, 23(6) : 686-693.]

[24] Chen Junqiang, Zhang Rui, Hou Yaochen et al. Relationships between species diversity and C, N and P ecological stoichiometry in plant communities of sub-alpine meadow. Chinese Journal of Plant Ecology, 2013, 37(11) : 979-987(in Chinese with English abstract). DOI 10.3724/SP.J.1258.2013.00101. [ 陈军强, 张范, 侯尧宸等. 亚高山草甸植物群落物 种多样性与群落 C、N、P 生态化学计量的关系. 植物生态学报, 2013, 37(11) : 979-987.]

[25] Yan Bangguo, He Guangxiong, Li Jichao et al. Changes of plant leaf N, P, and K concentrations and species dominance in an arid-hot valley after ecosystem restoration. Chinese Journal of Applied Ecology, 2013, 23(4) : 956-960( in Chinese with English abstract). [闻帮国, 何光熊, 李纪潮等. 生态系统恢复后干热河谷植物叶片 $N 、 P 、 K$ 含量及物种优势 度的变化. 应用生态学报, 2013, 23(4) : 956-960.]

[26] Lin Li, Li Yikang, Zhang Fawei et al. Soil nitrogen and phosphorus stiochiometry in a degradation series of Kobresia humulis meadows in the Tibetan Plateau. Acta Ecologica Sinica, 2013, 33(17) : 5245-5251 (in Chinese with English abstract). DOI 10.5846/stxb201205310797. [林丽, 李以康, 张法伟等. 高寒矮嵩草群落退化演替系列氮磷生态化学 计量学特征. 生态学报, 2013, 33(17): 5245-5251.]

[27] Yang Jiajia, Zhang Xiangru, Ma Lusha et al. Ecological stoichiometric relationships between components of Robinia pseudoacacia forest in Loess Plateau. Acta Pedologica Sinica, 2014, 51(1) : 133-142(in Chinese with English abstract). DOI 10.11766/trxb201211280492. [杨佳佳, 张向茹, 马露莎等. 黄土高原刺槐林不同组分生态化学计量关系研究. 土 壤学报, 2014, 51(1): 133-142.]

[28] Li Congjuan, Lei Jiaqiang, Xu Xinwen et al. The stoichiometric characteristics of C, N, P for artificial plants and soil in the hinterland of Taklimakan Desert. Acta Ecologica Sinica, 2013, 33 (18) : 5760-5767 (in Chinese with English abstract). DOI 10.5846/stxb201304300872. [李从娟, 雷加强, 徐新文等. 塔克拉玛干沙漠腹地人工植被及土壤 CNP 的化学计量特征. 生态学报, 2013, 33(18): 5760-5767.]

[29] Lin Xinjian, Wang Fei, Wang Changfang et al. Effects of long-term fertilization on weed community characteristics and carbon, nitrogen and phosphorus stoichiometry during winter-spring season in yellow-clay paddy fields of South China. Chinese Journal of Eco-Agriculture, 2012, 20 (5) : 573-577 (in Chinese with English abstract). DOI 10.3724/SP.J.1011.2012. 00573. [林新坚, 王飞, 王长方等. 长期施肥对南方黄泥田冬春季杂草群落及其 $\mathrm{C} 、 \mathrm{~N} 、 \mathrm{P}$ 化学计量的影响. 中国生 态农业学报, 2012, 20(5): 573-577.]

[ 30 ] Bin Zhenjun, Wang Jingjing, Zhang Wenpeng et al. Effects of $\mathrm{N}$ addition on ecological stoichiometric characteristics in six dominant plant species of alpine meadow on the Qinghai-Xizang Plateau, China. Chinese Journal of Plant Ecology, 2014, 38(3) : 231-237(in Chinese with English abstract). DOI 10.3724/SP.J.1258.2014.00020. [宾振均, 王静静, 张文鹏 等. 氮肥添加对青藏高原高寒草甸 6 个群落优势种生态化学计量学特征的影响. 植物生态学报, 2014, 38(3): 
231-237.]

[31] Ding Xiaohui, Gong Li, Wang Dongbo et al. Grazing effects on eco-stoichiometry of plant and soil in Hulunbeir, Inner Mogolia. Acta Ecologica Sinica, 2012, 32 ( 15 ) : 4722-4730 ( in Chinese with English abstract). DOI 10. 5846/ stxb201104200523. [丁小慧, 宫立, 王东波等. 放牧对呼伦贝尔草地植物和土壤生态化学计量学特征的影响. 生态 学报, 2012, 32(15): 4722-4730.]

[32] Hu Weifang, Zhang Wenlong, Zhang Linhai et al. Stoichiometric characteristics of nitrogen and phosphorus in major wetland vegetation of China. Chinese Journal of Plant Ecology, 2014, 38 (10): 1041-1052 (in Chinese with English abstract). DOI 10.3724/SP.J.1258.2014.00098. [胡伟芳, 章文龙, 张林海等. 中国主要湿地植被氮和磷生态化学计量 学特征. 植物生态学报, 2014, 38(10): 1041-1052.]

[33] Xiao Ye, Shang Lina, Huang Zhigang et al. Ecological stoichiometry characteristics of soil carbon, nitrogen and phosphorus in mountain swamps of Eastern Jilin Province. Scientia Geographica Sinica, 2014, 34(8) : 994-1001 (in Chinese with English abstract). [肖烨, 商丽娜, 黄志刚等. 吉林东部山地沼泽湿地土壤碳氮磷含量及其生态化学计量学特征. 地理科学, 2014, 34(8): 994-1001.]

[34] Bao Han, Qing Hua, Wang Lixin et al. A study on ecological stoichiometry of plant on lakeside zone of Lake Wuliangsuhai. Journal of Inner Mongolia University (Natural Science Edition), 2014, 45 (4) : 404-409 (in Chinese with English abstract). DOI 10.13484/j.nmgdxxbzk.20140412. [包菡, 清华, 王立新等. 乌梁素海湖滨带植物生态化学计量学研究. 内蒙古大学学报: 自然科学版, 2014, 45(4): 404-409.]

[35] Wang Weiqi, Wang Chun, Zeng Congsheng et al. Soil carbon, nitrogen and phosphorus ecological stoichiometry of Phragmites australis wetlands in different reaches in Minjiang River estuary. Acta Ecologica Sinica, 2012, 32(13) : 4087-4093 (in Chinese with English abstract). DOI 10.5846/stxb201106160817. [王维奇, 王纯, 曾从盛等. 闽江河口不同河段 芦苇湿地土壤碳氮磷生态化学计量学特征. 生态学报, 2012, 32(13) : 4087-4093. ]

[36] Liu Wenlong, Xie Wenxia, Zhao Quansheng et al. Spatial distribution and ecological stoichiometry characteristics of carbon, nitrogen and phosphorus in soil in Phragmites australis tidal flat of Jiaozhou Bay. Wetland Science, 2014, 12(3): 362-368 (in Chinese with English abstract). DOI 10.13248/j.cnki.wetlansci.2014.03.014. [刘文龙, 谢文霞, 赵全升等. 胶州湾芦苇潮滩土壤碳、氮和磷分布及生态化学计量学特征. 湿地科学, 2014, 12(3): 362-368.]

[37] Han Hua, Wang Haobin, Yu Huaguang et al. Ecological stoichiometry of carbon, nitrogen and phosphorus of Phragmites australis population under soil salinity gradients in Chongming wetlands. Resources and Environment in the Yangtze Basin, 2015, 24(5) : 817-823 (in Chinese with English abstract). DOI 10.11870/cjlyzyyhj201505014. [ 韩华, 王吴彬, 余华光 等. 崇明滩涂湿地不同盐度梯度下芦苇种群及土壤的生态化学计量学特征. 长江流域资源与环境, 2015, 24( 5): 817-823.]

[38 ] Liu Dahui. Study on the effects of mineral nutrition and its mechanism in the growth, secondary metabolism and quality of the medicinal plant Chrysanthemum morifolium(Ramat.) [Dissertation]. Wuhan: Huazhong Agricultural University, 2007 (in Chinese with English abstract). [刘大会. 矿质营养对药用菊花生长、次生代谢和品质的影响及其作用机理研究 [学位论文]. 武汉:华中农业大学, 2007.]

[39] Soil chemistry specialty committee of Soil Science Society of China ed. Conventional method of soil and agricultural chemistry analysis. Beijing: Science Press, 1983(in Chinese). [中国土壤学会农业化学专业委员会编. 土壤农业化学常规 分析方法. 北京:科学出版社, 1983.]

[40] Kang Yi. The research of soil physical and chemical properties and vegetations dynamics changes in Three Gorges Reservoir hydro-fluctuation belt [Dissertation]. Beijing: Chinese Academy of Forestry, 2010 (in Chinese with English abstract). [ 康义. 三峡库区消落带土壤理化性质和植被动态变化研究 [学位论文]. 北京: 中国林业科学研究院, 2010.]

[41] Guo Jinsong, Huang Xuanmin, Zhang Bin et al. Distribution characteristics of organic matter and total nitrogen in the soils of water-level-fluctuating zone of Three Gorges Reservoir area. J Lake Sci, 2012, 24(2) : 213-219(in Chinese with English abstract). DOI 10.18307/2012.0207. [ 郭劲松, 黄轩民, 张涁等. 三峡库区消落带土壤有机质和全氮含量分布 特征. 湖泊科学, 2012, 24(2): 213-219.]

[42] He Yang. Investigation of soil nitrogen and phosphorus in water fluctuation zone in central distract of Three Gorges Reservoir area and analysis of its release potential [Dissertation]. Chongqing: Chongqing University, 2009 (in Chinese with English abstract). [贺阳. 三峡库区腹心地带消落区土壤氮磷含量调查及其释放潜力分析 [ 学位论文]. 重庆: 重庆 大学, 2009.] 
[43] Ye Chen, Cheng Xiaoli, Zhang Quanfa. Characteristics of soil nutrient distribution in the water-level-fluctuation zone in the Three Gorges Reservoir, China. Chinese Journal of Soil Science, 2011, 42(6) : 1404-1410( in Chinese with English abstract). [叶琛, 程晓莉, 张全发. 三峡库区消落区蓄水前土壤养分分布特征. 土壤通报, 2011, 42 (6) : 1404-1410.]

[44] Guo Quanshui, Kang Yi, Zhao Yujuan et al. Changes in the contents of N, P, K, pH and organic matter of the soil which experienced the hydro-fluctuation in the Three Gorges Reservoir. Scientia Silvae Sinicae, 2013, 48(3) : 7-10(in Chinese with English abstract). DOI 10.11707/j.1001-7488.10120302. [ 郭泉水, 康义, 赵玉娟等. 三峡库区消落带土壤氮磷 钾、pH 值和有机质变化. 林业科学, 2013, 48(3) : 7-10.]

[45] Ye C, Cheng X, Zhang Y et al. Soil nitrogen dynamics following short-term revegetation in the water level fluctuation zone of the Three Gorges Reservoir, China. Ecological Engineering, 2012, 38: 37-44.

[ 46] Aerts R, Chapin III FS. The mineral nutrition of wild plants revisited: a re-evaluation of processes and patterns.Advances in Ecological Research, 1999, 30: 1-67.

[47] Ellison AM. Nutrient limitation and stoichiometry of carnivorous plants. Plant Biology, 2006, 8: 740-747.

[48] Yu Shuai, Chen Wei, He Xingyuan et al. Nitrogen and phosphorus contents of six herb species in riparian zone of Hunhe River, Northeast China. Chinese Journal of Ecology, 2012, 31(11) : 2775-2780( in Chinese with English abstract). [于帅, 陈玮, 何兴元等. 浑河河岸带六种草本植物氮、磷含量特征. 生态学杂志, 2012, 31(11) : 2775-2780.]

[49] Tilman D. Resource competition and community structure. Princeton: Princeton University Press, 1982: 139-177.

[50] Li Xiaofeng, Li Qiuhua, Qin Haoli et al. Distribution characteristics of N, P and K contents in 30 common plants from the hydro-fluctuation belt of Baihua Reservoir. Acta Scientiae Circumstantiae, 2013, 33(4) : 1089-1097( in Chinese with English abstract). DOI 10.13671/j.hjkxxb.2013.04.033. [李小峰, 李秋华, 秦好丽等. 百花湖消落带常见植物氮磷钾营 养元素含量分布特征研究. 环境科学学报, 2013, 33(4) : 1089-1097.]

[51] Wang Manlian, Feng Yulong. Effects of soil nitrogen levels on morphology, biomass allocation and photosynthesis in Ageratina adenophora and Chromoleana odorata. Chinese Journal of Plant Ecology, 2005, 29(5): 697-705 (in Chinese with English abstract). DOI 10.17521/cjpe.2005.0093. [王满莲, 冯玉龙. 紫茎泽兰和飞机草的形态、生物量分配和光合 特性对氮营养的响应. 植物生态学报, 2005, 29(5) : 697-705.]

[52] Marler RJ, Stormberg JC, Patten DT. Growth response of Populus fremontii, Salix gooddingii, and Tamarix ramosissima seedlings under different nitrogen and phosphorus concentrations. Journal of Arid Environments, 2001, 49: 133-146. 